\title{
MOBBING IN THE PROFIT AND NON-PROFIT SECTOR
}

\author{
Pavlína Haltofová ${ }^{1}$, Vendula Haltofová ${ }^{2}$ \\ ${ }^{1}$ Slezská univerzita, Obchodně podnikatelská fakulta, Univerzitní nám. 1934/3,73340 Karviná \\ Email:haltofova@opf.slu.cz \\ ${ }^{2}$ Realitní kancelář Sting, Radniční 344/25,787 01 Šumperk \\ Email:vendula@haltofova.cz
}

\begin{abstract}
Mobbing, terror and psycho terror are a kind of behavior which can be observed in labor law-related relations and which stress the ethics of organizations. The aim of the work is to discover a current situation and employees' awareness of mobbing. Social and economic incidences are investigated by analysis of literature, internet resources, fora and laws. In the Czech Republic, the direct or indirect experience of people with mobbing was mapped by the help of a questionnaire survey. The research confirmed that $33 \%$ of respondents are directly involved in mobbing, $63 \%$ know somebody in this situation. In the profit business, the mobbing is so often like in the non-profit sector. $32 \%$ of the victims leave work because of mobbing and in this way, the fluctuation of employees is rising up, affecting the economy of company or the organization in a negative way.
\end{abstract}

Keywords: labor law-related relations, mobber, non-profit sector, questionnaire survey.

JEL classification: C83, J24, L31, M14, Z13

Doručeno redakci: 6.10.2011; Recenzováno: 12.2.2013; 13.8.2012; Schváleno k publikování: 13.3.2013

\section{Introduction}

Labour-law relations, especially mobbing, are important players in the economic sphere, they largely share in the company profit, the success of the organization and its prestige among employees, partners, clients and customers. Some studies show that mobbing is involved in the liquidation of the organization from within. In the case of its occurrence, the labor productivity is declining rapidly, a team is unable to work as a team. The development of the whole organization is stagnating, and thus the success of the company also decreases in the fight with the competition. People affected by mobbing often leave the company with mental disorders and spread negative information about the organization. Some of them do not hesitate to publish their experience in the media, which does not certainly make a good image of the organization. Business owners, managers and entrepreneurs are often unaware of this fact.

The research of the company GfkCzech, s. r. o. shows that one in six of Czech met mobbing at work, i. e. slandering, ridiculing, invoking feelings of guilt or ill-aimed and constant, sometimes redundant or unjustified criticism of the work (Salátová 2007, online). In the Czech Republic, the concept of ethics in businesses only "settles". The survey, which ran from 1996 to 2000, shows that only $17 \%$ of questioned managers have developed a code of ethics. Most of the $86 \%$ feel a threat of the company based on an unethical conduct. But a business compliance is incompatible with ethical principles for many companies and businesses. Employees are only production units, are expendable, but nobody solves the problem of their feelings, ideas, states. They are simply dismissed from employment if redundancy. However share prices and the prestige of the company are declining with reports of the unethical conduct business. (The Economist 2000, p. 67-69)

Ethics and labour-law relations are an issue that is undoubtedly linked to the modern understanding of the concept work. These defined terms could also include the equally 
important as culture ${ }^{1}$ and morale ${ }^{2}$ that help to assemble the complete character of the working environment and help to understand the context of labour-law relations and ethics. In America, it has been fought against unethical behavior since the mid-80 years, and since the seventies, many U.S. companies have been pushed for it to be guided by ethical business principles (Šronek 1995, p. 165). There have been founded a number of institutions that watch over ethical behavior. CNN has been joined the battle and it seeks to publish all the unethical companies regardless of country boundaries. This penalty is for the international companies so large that it can cause (in many cases) to the crash. There have been created some institutions to help deal with the emergence of ethical codes in companies, to carry out an ethical audit, etc. (The Economist 2000, p. 67-69)

The corporate culture creates the conditions for conflict-free communication, it arranges and makes a clear view of the enterprise easier and makes it clear to colleagues and relatively easy to understand. Strong corporate culture also enables quick decisions, it accelerates the implementation of continuous innovation, reduces the need to control employees, increases the motivation and team spirit, ensures the stability of the social system. It has a low turnover of staff, their high motivation and loyalty. Weaknesses lie in tendencies to closure of business, in the traditions and a lack of flexibility, in blocking new strategies, a collective effort to avoid criticism, the enforcement of conformity at any price and in the complex adaptation of new employees. Corporate culture is often replaced with concepts as a corporate identity and a corporate image. (Nový 1993, p. 12-29)

The aim is to determine the current state of ethics in labor-law relations with the regard to mobbing in organizations. The work shall confirm the hypothesis that the awareness of mobbing and its impact on social and economic spheres (both profit and non-profit organizations) is not sufficient. We assume that people experience mobbing at work and do not often know how to solve it.

The study assumes that mobbing occurs in business more often, because it may be caused by a battle for prestige - money, so we have set the hypothesis that in the non-profit sector, there is a smaller part of those ones who are affected by mobbing than in the profit sector. Firstly, there is a literature search of the solved problem and then the primary research. This research is a survey focusing on the current situation in the labor-law relations with the respect to mobbing. To illustrate the situation, there have been surveyed online discussions with the issue. There are published both qualitative and quantitative results based on research.

\section{Ethical behavior in business and the reasons}

Ethical behavior of firms (in the long run) has a competitive advantage over the companies that behave ethically in most cases.

Business ethics itself is getting into the subconscious of both professional and nonprofessional public more and more. It becomes an important component of business, it is

\footnotetext{
${ }^{1}$ Culture can be characterized as a manifestation of people's association, it is a product of unnatural processes, it played an important role in the history of mankind. Culture is the values to which people report, standards they keep and material goods they produce. ... (Giddens 1999, p. 32)

${ }^{2}$ Morale is a product of this culture, it is closely linked with the culture, and it is developing on the basis of the processes of cultural behavior. Morale is still being changed and shaped the new changes, understanding change, the perception of values in society. Morale helps to organize social life of individuals and entities also the success and prosperity of business entities. Against the culture, it is the individual or the actual manifestation in the sphere of moral judgments, standards and rules of conduct. Morality versus ethics differs in that it is a state that there has been. On the contrary, ethics is a condition that should be optimal, i.e. normative setting. (Kárníková 1997, p. 5)
} 
a part of the curriculum at universities, the subject of lectures and one of the indispensable themes of consulting firms. "Summer school on ethics in business", which took place in April 1994 in Maastricht, talks of the importance of business ethics. The importance of business ethics is an even greater thanks the United Nations effort that seeks deal with this issue - for several years, there has been at the UN a commission which should establish the basic principles of business ethics.

Business ethics has its importance and necessity in business and management work precisely because entrepreneurs and managers are not only engaged in economic and technical activities, but also personal relationships and the organization of human resources (which must be consistent with the company needs but just with the demands and needs of workers) are an important component of their everyday decisions.

Putnová A. et al. (2000, p. 4-6) dealt with the research that was conducted on a sample of 89 companies with an industrial focus with 300 employees or more. The research objective was to find out how companies and managers know the code of ethics. $17 \%$ of the interviewed managers confirmed that the code of ethics is treated, almost half $(47 \%)$ of them was thinking of an elaboration. $77 \%$ of them agreed to cooperate, where there would be these topics processed, only $5 \%$ rejected it. The study conclusion shows that $78 \%$ of managers understand business ethics as a part of the company strategy. $62 \%$ of them admit that the failure of the rules of fair play significantly damage their business. $86 \%$ of surveyed managers feel a firm threat as a result of this breach of ethical rules. The managers rated the overall situation as bad. Many of them do not realize that our behavior shapes the business environment. They are both producers and consumers of this behavior and it is entirely in their best interest to seek a sophisticated and transparent business environment.

The external and the internal environment influence each other. Every company is exposed to a pressure from competitors, consumers, suppliers, etc. It is forced to adapt all its activities. This is also reflected in the relationships within the company. On the other hand, work ethics affects the product quality, productivity and costs, and by return, it influences the overall position of the enterprise market (Kárníková 1997, p. 83-86). Ethics plays a significant role in the relations. It is necessary to solve some of the natural relationships in emerging market economies which include the relationship between profit maximization and maximization of social utility (Kárníková 1997, p. 87). Managers and entrepreneurs should be provided with basic traits such as honesty, openness, an ability to act with people, justice and determination. If the company has the managers who are also enriched by courses or training on the subject of negotiation, bargaining, etc., a company with high morals has a far greater social responsibility. Able superiors effect on their workers as a model, and they lead by example.

In many cases, the managers can not cope by themselves, do not know how to communicate. The management can commit various errors in the company, they include numbness most often and sometimes even violence. These activities are emotionally dull, distorts character. For thicker specimens, this behavior manifests itself in the form of brutality against the collaborators, for weaker individuals in the form of fraud, falsehood, hypocrisy, etc. Other negative features of the bad management of the company may be a promoting disrespect of character traits or overloading employees, etc. Based on these facts, there arise problems in the company. The working environment is "thickening", conflicts are arising, productivity and quality are decreasing, and an axle, respectively putting everything back to normal is very difficult, sometimes impossible. These conflicts often produce the behavior that has been 
manifested in labor relations for a few decades. This is behavior English named by words mobbing, bossing, bullying.

\section{Mobbing}

Frequent symptoms of malfunctioning or uneducated management system are just mobbing, bossing ${ }^{3}$ or bullying ${ }^{4}$. This is a state of the behavior that has far-reaching consequences across the work and private life. In the Czech Republic, there is no direct institution which could help so disabled people. The word mobbing comes from the English word "mob" and in translation, it means vulgar scold, mob, run hard. Mobbing is considered as a psychological terror where intrigue and bullying become a routine, when the victim is attacked by one or more persons at least once a week for at least 6 months (Huberová 1995, p. 47). This term is also used in ethology, Konrad Lorenz introduced it. The meaning of the word describes a behavior of animals, such as a herd defending their territory against intruders by it that they attack as a whole.

In English speaking countries, it is used the expression of "emocional abuse" (emotional abuse, emotional maltreatment) for bullying at work. In the Czech Republic, we can find, except the expression of mobbing the name "terror in the workplace" or "psychoteror". It is any abusive behavior manifested in actions, words, gestures, texts. The result is to damage a person, their dignity, physical or psychological integrity of individuals, it threatens their place in the workforce or it devalues the work climate. It is bullying in the workplace at a seemingly intelligent and cultured people in offices, in newsrooms, it is known as mobbing in health care. From our current and known bullying, it differs especially in a high degree of psychological and modest percentage physical attacks, a higher proportion of snitching to seniors and intrigues, in a reduced physical threat, but with the same psychological, psychosomatic and social consequences and particularly in a high degree of existential threat. It varies significantly in motives unlike ordinary bullying. For the common bullying, a motif is characterized by an irrational desire for power and creating a false sense of security. Mobbing has rational elements on the contrary. In a situation where the existence of every working man is uncertain and the threat of dismissal is great, mobbing is intended to make a problem employee from another person, make him a target of criticism and various disciplinary measures and, of course, the first candidate of the statement at the earliest opportunity "reorganization." This allows other people to survive the next round. (www.volny.cz, online)

\footnotetext{
3 Bossing is a kind of the subset of mobbing. It is specified with it that the harassment is perpetrated by a supervisor. Its basic themes include jealousy of a capable worker and a concern about their position. A significant motif is also anger at the organization and hatred towards superiors (who showed them confidence and entrusted the leadership). (www.volny.cz, online 20th June 2010)

${ }^{4}$ Bullying: This is the behavior of harassing, injuring or inducing the state of discomfort, danger, fear, etc. It is always motivated, but often keyed, hidden, an interest to damage another, to hurt them. In this case, the point is a distorted use of the biological equipment of the individual aggression, bullying wearer. Buller can be alone for their aggression and need no longer or another relationship with the victim, with whom they currently play. A buller has strongly general, manipulatively selfish tendencies. They are not interested in feelings of others unless they are very excitable and irritating. In this case, they are the aggravating circumstances for the victim. We can not definitely ignore them as an employee, co-worker. They are not in hiding. Unlike a mobber who uses sophisticated more ritualistic practices a buller is in this planned action for the first time. (Beroušek 2001, p. 26) Some authors consider bullying as a synonym for the word mobbing, with the difference that they use this term in English speaking countries. (Krymláková et al. 2010, p. 150).
} 
Mobbers are frustrated, insecure people with the desire to dominate. The most frequent victims of mobbing are good-hearted, passive, timid, but also arrogant men (Hloušková 2002). Mobbing also makes use of physical influences. Whether there are situations at work where employees will always remain the worst table, computer, at schedule missions, there always fits them the worst, longest and most difficult route, or employees who have children at home, always get a shift on a holiday, although a half of their employees is without children, this is mobbing. These situations and conditions are unfortunately hard to prove. (Novák, Capponi 1996, p. 73)

Mobbing can be considered different forms and procedures. It can be an attack on an opportunity to comment or to trust (a constant interruption, boundless criticism, threat). It may be attacks on social relations (it is not "told" with you, you are air, you are separated from yours colleagues, ostracism), or attacks on your reputation, respect and reverence (slanders, ridicule, belittlement of your nationality, religion), or attacks on the work or personal life quality (meaningless work tasks, an impossible task), and attacks on health (work which injures your health, a threat of physical violence, sexual harassment). (Beňo 2002, p. 4-5.)

How and to whom you may claim mobbing? A colleague can attack a colleague, or a boss can attack a subordinate, or vice versa a subordinate can attack a supervisor (Sýkorová 2004). A mobber systematically builds a situation where the victim feels more and more feelings of guilt for that a group refuses them. These situations are gradually and systematically constructed, a mobber is also building an action team player of mobbing, directed by their autocratic scenarios. Almost always, the mobber occupies two roles. In the first one, they act as a messenger of good news, they are kind and sweet, on the other hand they play a huffing and serious person. Sooner or later, the combination and alternating roles bring the desired results, which is a succumbing to the victim. Other team members are numerous viewers, who like to build into the roles of statistics.

The sad paradox is that the number of mobbers is not decreasing under onerous socioeconomic conditions and that they are, in not a few cases, a significant factor in liquidation of the company from within, because the labor productivity significantly decreases by their effects, the ability to work teams to overcome economic difficulties by full real hard work. A sanitation management ability is often (more or less) paralyzed to recognize "the frog in the spring." (Beroušek 2001, p. 27)

Valášek (1998) distinguishes between men and women as mobbing persons. According to his information women use more hypocrisy, slander, intrigues during mobbing they can play a theater, etc., in simpler terms they use lighter ways more than men who are harder and colder in this fight. They prove in a battle who is stronger, they humiliate victims, a mobber as a chief isolates the victim he settles it in a tucked workplace, he gives tasks under the qualification of the victim, which leads to a wound of his self-confidence, etc. A mobber can be distinguished as a man with a more open and more direct emotional speeches, on the other side with a theatrical output of mobber in the female version. (Beroušek 2001, p. 26-29)

Conflicts that arise in a working group are an indicator of internal disharmony relations. They represent the cornerstone of interpersonal relationships, they test an inner strength of the work team, resilience, a viability of the group they may be potential milestones in its future development. Mobbing can manifest itself very darkly in the early stages and the victim does 
not have to realize at the beginning that the behavior is guided targeted against it. (Štikar et. al. 2000:95)

The aim of mobbing is to damage another and thus to remove the worker from employment. According to studies, surprisingly, the perpetrators are not only superiors (37\%), but mainly co-workers $(44 \%)$, followed by colleagues who are connected with superiors $(10 \%)$ and finally subordinates to superiors (9\%). (Valášek 1999)

\subsection{Phase of mobbing}

The first conflict is usually due to misunderstandings, information noise, they are not targeted. Small deliberate and gossip, withholding information are the most common, not even a planned behavior. The next phase is already the transition to a systematic psychoteror. The difference comes in the fact that the activities are planned and executed with the intention to harm another. In the third phase there is a specific attack, accusations, work overload. The mobber is described as the "black sheep", the case becomes official, which leads to injustice, and mobbing receives blessing from the management company. Sometimes the victim takes the wrong end, ie. that everything is repeated, and the victim does not defend against. The constant quarrels or absence and reduced work activity under the influence of constant stress are the evidence of which side is to guilty. The scapegoat becomes logically the victim to their superiors who do not listen or are plotting behind his back. (www.doktorka.cz, online)

In the end that the scapegoat was literally straitened into his dismal state, few people are interested, and especially few people think of. The usual go-round, which begins interviews with the head, ultimatum, vows, is following. The leader himself turns against the victim because the victim really begins to accumulate errors under the pressure, which is the evidence of their "troubles" and "proof" of the fact that they are considered "objectively" by their surroundings. (www.volny.cz, online)

The last phase is the phase that we could call with one word - "exclusion". After all these complications when the leadership does not usually follow any causes of the decline of labor supply and worker errors, the leadership has one goal - to get rid of the troublesome worker. If the victim does not want to leave voluntarily, the whole range of means are found to destroy them. First, the worker is relegated from a department to a department, their responsibility is limiting, they are still checked and everything is prepared for their departure. The mobber is broken in the whole structure of his personality and they commonly show signs of behavior that had initially been wrongly reproached.

\subsection{Causes of mobbing}

The cause is not clear there is another reason for each job and the type of people. In most cases, however, there are reasons because of a sense of social danger, a fear of unemployment of the mobber - they rather edge out a more high-quality collaborator than to live in a fear of losing their job. A common assumption of mobbing is a low corporate culture that is very suitable environment for unethical conducts which the company does not deal with anyone because it can not even solve. The reason may be envy, competitive relationships, a fear of an older worker of the arrival of a younger one - perhaps more competent, while young team can make mobbing older individuals, because it is a closed group that does not accept new members, etc. Last but not least factor that affects mobbing is also the structure of personality of the mobber and the man that suffers from mobbing. If the employee has a prerequisite for work bullying and terror, and chooses a victim who can not defend the problem is in the 
world. According to other sources mobbing is nourished by the atmosphere of a market economy where there is a threat of a tough competition and high unemployment.

An officer who is responsible for the working atmosphere is guilty. If a manager misses the basic moral qualities and the necessary legal knowledge, they virtually make a signal for a development of bullying - mobbing in the workplace. Such a leader often has a complex and a strong need to control people and manipulate them. They usually surround their famous pack of servile and weakling, to whom they offer various benefits (working visibility, sense of power, rewards, etc.). For these benefits, they require the complete subservience of their friends, including snitching. (Kocábek, mpsv.cz, online)

\subsection{Consequences and dangers of mobbing}

Mobbing has a double risk - primarily it affects employees and then the company name.

$16 \%$ of persons of the entire sample became the victim of mobbing according to a research of the company GfK Czech, s. r. o. Praha in 2001. $20 \%$ of all suicides are just caused by mental states of the man who suffer from mobbing. (Salatová 2007, online) It was $10 \%$ in 1996 (Novak, Capponi 1996, p. 76). In the best case the "affected" people change into a man with psychosomatic symptoms, they lose their confidence, begin to doubt of themselves seriously, damage themselves, have a feel that they are paranoid, etc. If we want to include mobbing in the ranking of stressful events on the scale of Holmes and Raheho, although this condition is evaluated lower than the death of a partner (100 points), it can be compared to the divorce (73 points). We mention the death of a close family member (63 points) for a comparison, and a job loss (47 points). (Novak, Capponi 1996, p. 83)

Mobbing, actually the ethical reputation of a company can have an effect on stock prices, which "fall after the public leak reports of unethical conduct." The bad behavior of individual firms stirs up a public opinion, a discussion on this topic results and all this could provoke legislative changes that rather go on nerves of companies than to help to a greater selfdiscipline. And the companies, in which their employees, partners, customers do not trust at the time of the electronic age, will suffer from a loss of confidence. In the end, companies will have to make the fact up that the virtue is sometimes also a reward. One of the factual truths of morality is that the poor are not always bad and good is not always good. (The Economist, 2000, p. 67-69)

\subsection{Defense against mobbing, problem solving}

The defense against mobbing can be considered in two respects again. First, it is important to know how an individual shall defend, respectively each of the working people and secondly, how the employer shall defend. The possibility of defense of employees may consist in a healthy self-confidence and assertive behavior from the beginning, when a mobber begins to work. Another option is a special psychological and socio-therapeutic course that helps victims to deal with the situation. (Beroušek 2001, p. 26-29)

Vlašák (1998) states that the defense is to make mobbing too. This idea is not from his head, he used the book by Wolfharta Berga as the theme - Tips and tricks how to make a steep career, and it is recommended to become a perpetrator before someone throws us to devour by wolves living in all areas of human activity. Hloušková (2002) recommends as a defense for the victim to be active. The network of contacts will help to learn about plots, it is possible to intervene early. Criticize with tact. Finally, she put the question whether it is right to howl with the wolves if we and our children will want to be in such a world, and whether such a 
career is worth. Valášek (1999) shows an offered defense in his study. If the victim will not solve the situation with a mobber in the early stages, they resort to a resign at the position in the company. He recommends to find an alternative employment quickly through an advertisement or through friends and relatives.

Another solution to the situation can be a reporting the problem to a supervisor, and then seen what culture the organization has. One should not give up and should seek a support and finding a decent and honest man as a kindred soul who will help them in the fight against mobbing. The sacking means actually a relief and liberation for the victim, there is not a tragedy in any case. If the victim behaves where "nobody is above anyone and do not abase before anyone" and if this is perceived by surroundings, they will always find a job in their field. Thus "head up"! (Kocábek, mpsv.cz, online)

For those people looking for a job, or planning to change the workplace, it is the recommendation of doctor Anna Sýkorová, who has three tips on how to prevent mobbing in the workplace and become an ideal subordinate. 1) To select a good job (a team, from which you do not have goose-skin and you enjoy the work). 2) A need of a high quality boss: hearty, generous, tolerant, successful. 3) To have suitable collaborators: powerful, intelligent, and responsible. This advice means that someone that is really happy does not envy, does not slander and does not hurt (Sýkorová 2005). One aspect of the problem is the impact on the economy of the company, where a mobber operates. A good employer get rid of the mobbers, because their presence in the workplace is very expensive, doctor Gary Namie, Workplace Bullying institute. (Svobodová 2008, p. 103)

If there is a problem in the organization, it is necessary for the manager to be able to negotiate and managed these conflicts. If the manager himself fails to these stages, it is appropriate to invite a facilitator to resolve the conflicts and problems in the workplace. This person makes easy the communication and mutual understanding, brings moments of mutual interest, builds the mutual trust, develops ideas of both parties and leads throughout the negotiations to find a joint decision. Its biggest advantage is impartiality and objectivity, because it only solves the situation it is not personal interest in the dispute (Štikar et al. 2000, p. 97). The facilitator may be the person, who works in this position directly in the company and resolves these disputes at different places in the company, or it may be an employee of an outside firm, which the company, where the problems happen, hires to solve these issues and teaches workers to prevent these situations in the future.

A denouncement has become a defense against mobbing and bossing even more often in recent years, as an employer would create friendly working conditions to his employee according to the law (Holá 2009). Mobbing is very difficult to prove, but if the victim has evidence, preferably someone who testifies that situation, plus a variety of materials and documents proving the guilt of mobbers, it is possible to go to court. A part of the victims does not know and does not hope to win the lawsuit, plus fees for court costs destroys a motivation to go to the war. Many judges also underestimate the mobbing situation and they take it (as well as some employers) as a normal part of the work process. These situations could be addressed by the Czech law, Act no. 262/2006 Collection of Law, Labour Code, especially $\S 7$, paragraph 3, 4, 5, § 187, paragraph 1, 2, § 9, § 10, or Act No. 435/2004 Colection of Law, Employment Code, especially $\S 139$, paragraph 1, 2, 6, Civil Code - Act No. 40/1964 Collection of Law, especially $\S 11, \S 13, \S 16$, Criminal Code No. 140/1961 Collection of Law, where there could be used for a solution of mobbing: the crime of false allegation ( $(174)$, the crime of unauthorized use of personal data ( $(178)$, disorderly conduct 
crime ( $(202)$, the crime of procuration ( $\S 204)$, the criminal act of endangering the morals ( $\S$ $205)$, the criminal act of slander ( $\S 206)$, the crime of bodily harm $(\S 221-224)$, the crime of threatening by venereal disease $(\S 226)$, the crime of illegal restraint ( $\$ 231)$, the criminal act of extortion ( $\S 235)$, the crime of repression ( $(237)$, the crime act against human dignity ( $\S$ 241 ), the crime act of sexual abuse of persons under eighteen years of age ( $\$ 243$ ), not least, the Constitution of the Czech Republic, Act No. 1 / 1993 Collection of Law and the Declaration of Basic Rights and Freedom - Law No. 2 / 1993 Collection of Law, which contains a large number of different definitions describing the situations that may be violated at mobbing (for example the Article 10, paragraph 1, 2, 3). From the perspective of the employer, people can defend mobbing, or proceed by an appropriately course not only workers of the personnel department, but most executives and managers. Equally important is the question of proper communication in business, time management, proper assigning tasks, inspections, valuations, rebuke, etc. All these activities fit together and prevent situations where mobbing can occur.

\section{The survey}

An anonymous questionnaire survey has carried out to capture the current situation ethics in labour-law relations. There has been drafted a questionnaire which has contained 12 questions in order to map the situation in the Czech Republic and to assess how many people have experienced mobbing personally or they know someone nearby that suffer from mobbing and whether they are aware of the potential solutions. The survey was conducted on a sample of 150 respondents, while we expected the return of at least $50 \%$ which had followed from the previous experience with a questionnaire survey. The basic sample was determined, by "blind estimate" for 75 to 90 respondents of profit and non-profit organizations as well without any other specification.

The determination of the basic sample can be done by setting the following formula:

$n=\frac{t^{2} \times P \times Q}{\delta^{2}}$

where $n$ is the file size, $t$ is the reliability coefficient, whose size depends on the reliability, $P$ represents the proportion of units that show an alternative one and $Q$ is the proportion of units showing an alternative two and $\delta$ is the allowable percentage error (it is used by Kozel, Mohelská 2010, p. 136). In our case, the first alternative is a man who has not met illegal activities in the employment and alternative two is a man who has met such a behavior.

The value of 1.96 (Table 1) corresponds to the number of respondents for different alternatives in the chosen level of confidence $95 \%$, confidence coefficient $t$ (or standard normal quantile - Grosová 2002, p. 143)

Table 1: Number of respondents to different response alternatives

\begin{tabular}{|l|l|l|l|l|}
\hline \multirow{2}{*}{$\mathrm{P} \times \mathrm{Q}$} & \multicolumn{4}{|l|}{ The sample size for various permissible percentage error } \\
\cline { 2 - 5 } & 8 & 9 & 10 & 11 \\
\hline $0.8 \times 0.2$ & 96 & 76 & 62 & 51 \\
\hline $0.7 \times 0.3$ & 126 & 100 & 81 & 67 \\
\hline $0.6 \times 0.4$ & 144 & 114 & 92 & 76 \\
\hline $0.5 \times 0.5$ & 150 & 119 & 96 & 80 \\
\hline
\end{tabular}

Source: own questionnaire survey

The blind estimate corresponds to $8-9 \%$ error in the ratio of people with regard to the experience of illegal activities at work $80 \%$ and $20 \%$ and error 10 to $11 \%$ at other alternatives. 
80 respondents answered the questionnaires, which represent a 53\% return, and this corresponds to the blind estimation. The first 20 respondents were from a large international company that functions in services in the Czech Republic and that expresses the fact that it competes in the Employer of the Year competition every year where there is also placed it, so it is possible to believe that mobbing is a "foreign" word for this company. 20 respondents were people working in the non-profit sector, two of whom responded that they have had no experience with the issue of mobbing. They were the employees who work in a family organization. 40 respondents were ordinary working people of different ages from various companies. The polling was conducted electronically in the course of 2010 with a qualitative manner, with using of an accompanying letter that the situation introduced. Respondents were given 12 questions, and each individual could choose between a simple one-word answer, or a description of their view of things. There was not taken into account an age, gender, education and racial or religious establishment during the survey. From the above information, it is clear that these criteria are not standard as far as mobbing. The questionnaire is no part of the work due to the limited range of the publication, the individual questions are presented in the assessment. Answers from the questionnaire are assessed both quantitatively and qualitatively. Respondents from profit organizations were distinguished from non-profit organizations ones by purpose to compare them and set out possible differences if there are some.

\subsection{Evaluation}

\subsubsection{Solution of the situation without the Labour Code and the opinion of such actions (questions 1 and 2)}

$60.26 \%$ of respondents have encountered a situation that labor issues were dealt with a different way than in the Labour Code (Table 2). The cases mainly concern the time that is set aside for employee donations, non-compliance regarding wages, even though the written contract existed.

58 employees accept this conduct as negative they state that "it's sad" that these situations would not become that it is wrong, they disagree with them, "the situations would be addressed in the context of justice," "it's beastliness". They do not like that "it is illegal, but in our circumstances perfectly natural, if both sides have agreed on the matter, so it is acceptable", it holds by 17 respondents. One answer is strict, "that the Code should be observed," one can not comment it and the other takes it as part of life, others think that the violation is not quite as frequent.

Table 2: The answers of respondents to the question: "Have you ever met at work that the work issues were solved otherwise than it is specified in the Labour Code?"

\begin{tabular}{|c|c|c|c|c|c|c|}
\hline \multirow[b]{2}{*}{ Type of organization } & \multicolumn{6}{|c|}{ Number of replies absolutely and relatively } \\
\hline & Yes & $\%$ & No & $\%$ & $\begin{array}{l}\text { Do not } \\
\text { know }\end{array}$ & $\%$ \\
\hline Non-profit organizations & 10 & 55.56 & 8 & 44.44 & 0 & 0.00 \\
\hline Large company & 14 & 70.00 & 3 & 15.00 & 3 & 15.00 \\
\hline Other companies & 23 & 57.50 & 17 & 42.50 & 0 & 0.00 \\
\hline Profit sector total & 37 & 61.67 & 20 & 33.33 & 3 & 5.00 \\
\hline TOTAL & 47 & 60.26 & 28 & 35.90 & 3 & 3.84 \\
\hline
\end{tabular}

Source: own questionnaire survey 


\subsubsection{Awareness or experiencing bullying or a similar situation personally or at friends and how they can defend (questions 3, 4 and 5)}

More than a third of respondents have felt a hostile environment in their work, whether we call it bullying or terrorizing. Five respondents solved this situation by leaving the work, one solved it with an official complaint, one asked their rights at the office, where he was told that the only possible solution is the court, one respondent referred to the Labour Code. Another one states that they had any chance to react. Others have tried to discuss and convince the management or colleagues about their qualities and how it really is. Two people did not defend at all and three were trying to adapt and satisfy their colleagues. More than $60 \%$ of respondents know someone in their neighborhood that is experiencing mobbing, or a similar behavior in the workplace.

Table 3: The answers of respondents to the question: "Have you ever been psychologically terrorized, bullied or fired from work just because you were displeased by your boss?"

\begin{tabular}{|l|r|r|r|r|}
\hline \multirow{2}{*}{\multicolumn{1}{c|}{ Type of organization }} & \multicolumn{4}{c|}{ Number of replies absolutely and relatively } \\
\cline { 2 - 5 } & Yes & \multicolumn{1}{c|}{ No } & $\%$ \\
\hline Non-profit organizations & 6 & 33.33 & 12 & 66.67 \\
\hline Large company & 8 & 40.00 & 12 & 60.00 \\
\hline Other companies & 12 & 30.00 & 28 & 70.00 \\
\hline Profit sector total & 20 & 33.33 & 40 & 66.67 \\
\hline TOTAL & 26 & 33.33 & 52 & 66.67 \\
\hline
\end{tabular}

Source: own questionnaire survey

Table 4: The answers of respondents to the question: "Do you know someone in your neighborhood that had any similar experience with this behavior in the workplace?"

\begin{tabular}{|l|r|r|r|r|}
\hline \multirow{2}{*}{\multicolumn{1}{|c|}{ Type of organization }} & \multicolumn{4}{c|}{ Number of replies absolutely and relatively } \\
\cline { 2 - 5 } & Yes & $\%$ & No & $\%$ \\
\hline Non-profit organizations & 14 & 70.00 & 6 & 30.00 \\
\hline Large company & 13 & 65.00 & 7 & 35.00 \\
\hline Other companies & 23 & 57.50 & 24 & 42.50 \\
\hline Profit sector total & 36 & 60.00 & 30 & 40.00 \\
\hline TOTAL & 50 & 62.50 & 37.50 \\
\hline
\end{tabular}

Source: own questionnaire survey

\subsubsection{How is a termination of employment solved in the workplace? (question 6)}

Most respondents (84 \%) said that by an agreement or according to the Labour Code with a severance pay. A few of them have not known, another solution has been a transfer, or a forced settlement for the exit speeding $(7.5 \%)$.

\subsubsection{How to prevent bullying and is it even possible? (question 7, 8 and 11)}

In summary we can say that more than $68 \%$ of respondents would know how to resist bullying and how to behave in this situation (Table 5). It is recommended to communicate with a superior, or directly with the mobber. If the mobber was the direct supervisor, it would be solved with a lawyer, the police, using civic centers and they would seek another employment.

In contrast, there arises the question whether mobbing can not be defended by themselves. Most respondents have agreed that yes $(94 \%)$. A third of them believe that it depends on the nature and the courage of a man who must be mentally strong and balanced, and that in most cases, it is not possible according to every third respondent, particularly in cases when there is bullying of the supervisor. 
According to respondents, the most common solution would be to solve the situation with your boss or someone that solve these situations in the company (35\%). The second most common answer would be a departure from work (32 \%). It could adversely affect the organization in term of the economic aspect, because it can be increased spending not only on train new employees by the staff turnover, not to mention the possible "good" advertising released. It can be reduced marketing by professional users, staff leaving, or vice versa, the organization will have a problem with seeking of quality employees. Many managers and leaders of organizations do not realize these factors.

Table 5: The answers of respondents to the question: "Do you know what to do in a situation where someone is bullied at work?"

\begin{tabular}{|l|r|r|r|r|}
\hline \multirow{2}{*}{ Type of organization } & \multicolumn{5}{|c|}{ Number of replies absolutely and relatively } \\
\cline { 2 - 5 } & \multicolumn{1}{|c|}{ Yes } & \multicolumn{1}{c|}{ \% } & No & \multicolumn{1}{c|}{$\%$} \\
\hline Non-profit organizations & 16 & 80.00 & 4 & 20.00 \\
\hline Large company & 13 & 65.00 & 7 & 35.00 \\
\hline Other companies & 26 & 65.00 & 14 & 35.00 \\
\hline Profit sector total & 39 & 65.00 & 21 & 35.00 \\
\hline TOTAL & 55 & 68.75 & 25 & 31.25 \\
\hline
\end{tabular}

Source: own questionnaire survey

Some respondents recommend taking part in the conflict with a lawyer (5\%), which could ultimately mean some unexpected expenses (in the event of litigation) or a bad publicity and an adverse publicity for the organization. Another recommendation of some respondents is an improvement on their side, not to make mistakes and not to give excuses for bullying, as well as media coverage, or even physical assault of mobbers in one case. Some do not know whether it would depend on priorities in the given situation $(20 \%)$.

\subsubsection{Would be there interested in counseling which addresses the labor-law relations of employees? (question 9)}

Over $82 \%$ of respondents would welcome a high-quality counseling, in which people would help disadvantaged workers (Table 6). One respondent said that it could be a good price and one said that it would be better to resolve the situation in the workplace. Another point of view affirms that it is unnecessary, there should work a correctly union, or that there are a lot of counseling of this type. Some men would welcome a counseling in their place of residence or an Internet form. One replied: "Not really, every man can solve this problem alone".

Table 6: The answers of respondents to the question: "Would you like a quality counseling which would help thus disadvantaged people?"

\begin{tabular}{|l|r|r|r|r|}
\hline \multirow{2}{*}{\multicolumn{1}{|c|}{ Type of organization }} & \multicolumn{5}{c|}{ Number of replies absolutely and relatively } \\
\cline { 2 - 5 } & Yes & $\%$ & No & $\%$ \\
\hline Non-profit organizations & 13 & 72.22 & 5 & 27.78 \\
\hline Large company & 16 & 80.00 & 4 & 20.00 \\
\hline Other companies & 35 & 87.50 & 5 & 12.50 \\
\hline Profit sector total & 51 & 85.00 & 9 & 15.00 \\
\hline TOTAL & 64 & 82.05 & 14 & 17.95 \\
\hline
\end{tabular}

Source: own questionnaire survey

\subsubsection{Would training courses improve the situation in labor-law relations? (question 10)}

The idea is at the level of the respondents (Table 7). We can say that this need is felt by more respondents from profitable firms than unprofitable. The respondents who answered that a training is not necessary, said the reason that mobbing is a matter of a particular man, and if 
it hurts, do it consciously. Some men said that the courses would be necessary not only for personal departments, but also for employees to know how to act against such practices.

Table 7: The answers of respondents to the question: "Do you think that training courses for company management and personnel department would improve the situation?"

\begin{tabular}{|l|l|l|r|r|r|r|}
\hline \multirow{2}{*}{ Type of organization } & \multicolumn{7}{|c|}{ Number of replies absolutely and relatively } \\
\cline { 2 - 8 } & \multicolumn{1}{l|}{ Yes } & \multicolumn{1}{c|}{ No } & \multicolumn{1}{c|}{$\begin{array}{c}\text { Do not } \\
\text { know }\end{array}$} & \multicolumn{1}{c|}{$\%$} \\
\hline Non-profit organizations & 6 & 30.00 & 12 & 60.00 & 2 & 10.00 \\
\hline Large company & 10 & 50.00 & 10 & 50.00 & 0 & 0.00 \\
\hline Other companies & 23 & 57.50 & 14 & 35.00 & 3 & 7.50 \\
\hline Profit sector total & 33 & 55.00 & 24 & 40.00 & 3 & 5.00 \\
\hline TOTAL & 39 & 48.75 & 36 & 45.00 & 5 & 6.25 \\
\hline
\end{tabular}

Source: own questionnaire survey

\subsection{General view of the situation}

The questionnaire survey has confirmed one of the hypotheses - the fact that fewer respondents met mobbing in the non-profit sector than in profitable firms. This may be due to the fact that the priority in these types of organizations is a mission and a gain at another location. The situation is not favorable for the CR. Although mobbing may not be a word commonly used for people, many of them has already met this situation in their life and whether in their own skin $(33.33 \%)$, or they have heard about it from their friends $(62.5 \%)$.

\section{Mobbing in web discussions}

Internet news portals, blogs have been a very important source of information in the last few years. They guarantee the confidentiality, but on the other hand, a possibility of the great openness to describe the problem. The problem is for many victims so confining that they are silent among their loved ones and often even their family and closest friends do not know what's happening at work. The Internet portals provide us the opportunity to share their negative experiences and in many cases to get feedback, either through counseling servers or through any Internet users who find the problem on the site and respond to it. There has been conducted a survey about mobbing on the web discussions. This information was not crucial, but they have a great meaningful qualitative value because they are the authentic testimony on the subject.

When searching the discussions we have found tens of diverse contributions, from which we can only see the part of the employee $=$ the victim. Any pages mobbers we could not find. There has not been also found a page where the companies, entrepreneurs and leading of companies would inform about how to defend against mobbers. The other, though such an important side of this thing, is not discussed at all and is ignored.

The discussions show that the victims of mobbing are stressed and do not know where to find a support. In some cases, they leave work and give up any fight. It is obvious that this is a very subjective description of the situation and the reader does not have any sufficient evidence to prove to assess the situation objectively. We can get the impression that the victim is an employee, but we do not know all the causes of the behavior of colleagues or senior to them. This does not disprove the fact that the right manager would not allow such a situation, or they should precede it.

These are often people who have problems to integrate into a new working team, still suspect their entourage and are not sure themselves. The more affected group uses antidepressants and 
attends a psychological counseling. The happier ones fought, and either succeeded and left their work with a severance pay or the mobber was sacked base on an assessment of the educated manager.

\section{Conclusion}

The mobbing can be seen from both the employee and by the victim. The conducted literature search indicates that the problem of mobbing in organizations exists largely and an immediate superior has the main blame. The superior is in a poor contact with their subordinates and can not detect the problems early. If a mobber, respectively a boss is the boss himself directly, there is an error in the management of the organization. The cause may be in a poorly mastered selection process for this position, where there could be detected some preconditions for an unethical conduct.

The victim usually suffers from psychosomatic and psychological disorders, they lose their work and self-confidence. There are some organizations abroad that struggle with this problem. People in the CR have a foothold in the law, particularly in the terms of the violations of the personal privacy, harassment, extortion, etc., but Internet discussions show that people can not fight with the problem of mobbing and seek help in online discussions, where they appeal to the other in an attempt to find a solution of their critical situation in employment. It is evident the absence of counseling which was also confirmed by $82 \%$ of respondents in the survey. The results of the survey are proportional to the number of respondents and they must be seen as follows.

The survey also has showed that $33 \%$ of those interviewed people met mobbing personally. $63 \%$ of respondents know someone in their neighborhood who suffers from mobbing. Nobody does solve the economic impact on the organization, although the staff turnover can be significant. $32 \%$ of respondents said that they would leave work in the case of psychological terror, or it has been already done and they work elsewhere. $35 \%$ said they would address the situation through a consultation with the supervisor. If the manager was educated in all aspects, these people could be successful. We confirmed the first hypothesis that the awareness of mobbing and its impact on social and economic spheres (both profit and non-profit organizations) seems to be not sufficient.

Confirmation of the hypothesis, that people experience mobbing at work do not often know how to solve it, is not unequivocal, but only $5 \%$ of respondents would address the situation with a lawyer. If the "mobber" is a strong personality capable to provide an evidence of psychological terror, his complaint might threaten the reputation of the organization, which can cause an outflow of customers, but also workers. Many managers are often unaware of these facts. In the case of non-profit organizations, it could be lost credibility in the eyes of donors, agencies, who support the organization financially.

The research has not confirmed the third hypothesis that employees in the non-profit sector are affected by mobbing a lesser extent than in the profit sector. We could assume that this was because of the fact that in the nonprofit sector there is not so much about the career and struggle to gain of control workers whose primary motivation is a mission, mostly in the nonstate non-profit sector, but our results did not confirmed it. Because we did not established sufficient criteria for the selection of profit and non-profit organizations, and the basic sample of questionnaire survey was determined, by "blind estimate" for 75 to 90 respondents of profit and non-profit organizations as well without any other specification, the results are in quantitative terms rather informative. Their weight lies in the qualitative evaluation. 
The literature often analyzes only an impact on the psyche of the victim. An impact on a company or another organization is observed little. Due to bad managers, they often lose quality employees, teams, profits, clients. If an employee is satisfied, we can observe some signs of the psyche of a man, which are the motivational factors, needs, expectations, satisfaction, frustration of needs, turnover and absenteeism, job performance, adaptation, overall satisfaction with life and constructive development of personality. There is no advice how to behave at work, both from the position of a manager, and from a position of employees. Each type of an organization has its own specific characteristics which must be adapted to the behavior. But if we follow the communication skills and choosing the right manager, we will reduce the risk of conflict in the workplace or mobbing to start a business of discharges to his colleagues.

In the current situation of capitalist society, it is crucial for employees not to lose jobs, because they live so-called in a loan and must repay a mortgage every month. If they occur in such a situation, it may be a reason why they are bullied at work and do undertake nothing against it. They are under pressure from the banks, their family (which they must nurture) and a manager would be able to exploit this situation. The question of rates and other factors impact on psychological well-being of employees at work was not asked, but it could be a topic for a further research.

\section{References}

[1] BEŇO, P., 2002. Mobbing je když....Moderní vyučování.roč. 8(3), 4-5. ISBN: 1211-6858.

[2] BEROUŠEK, P., 2001. O agresi v našem životě, časopis Personál, č. 9, str. 26-29

[3] Etika má cenu, 2000. The Economist, 2000(19), 67-69.

[4] GIDDENS, A., 1999. Sociologie. Translated by Jan Jařab. 1. vydání. Praha : Argo. ISBN 80-7203-124-4.

[5] GROSOVÁ, S., 2002. Marketing: principy, postupy, metody. 1. vydání. Praha : Vysoká škola chemicko-technologická v Praze. ISBN 80-7080-505-6. [online]. [vid. 22. února 2010]. Dostupné Z: http://vydavatelstvi.vscht.cz/knihy/uid_isbn-80-7080-5056/pdf/143.pdf

[6] HLOUŠKOVÁ, I., 2002. Jak se bránit mobbingu. IHNED.cz, [online]. [vid. 1. května 2010]. Dostupné z: http://ihned.cz/1-10023710-11010330-000000_save-ce

[7] HOLÁ, M., 2009. Mobbing aneb šikana na pracovišti. Zdrave.cz[online]. [vid. 1. května 2010]. Dostupné z: http://www.zdrave.cz/magazin/psychologie-a-vztahy-14/mobbinganeb-sikana-na-pracovisti-302/

[8] HUBEROVÁ, B., 1995. Psychický teror na pracovišti - mobbing. 1. vydání. Martin : Neografia. ISBN: 80-85186-61-6.

[9] KÁRNÍKOVÁ, J., 1997. Etika v podnikání a ř́díci práci. Praha : Vysoká škola ekonomická, Fakulta financí a účetnictví. ISBN: 80-7079-524-7.

[10] KOCÁBEK, P., 2008. Jak „přežit“ šikanu aneb mobbing na pracovišti, [online]. [vid. 1. května 2010]. Dostupné z:http://www.mpsv.cz/cs/5162

[11]KOZEL, T. a M. MOHELSKÁ, 2010. Modely firem s mobilně orientovanou architekturou. E+M Ekonomie a Management. 13(4), 135-142. ISSN 1212-3609.

[12]KRYMLÁKOVÁ, K. a kol., 2009. Etika a odpovědnost organizace. Ostrava : Vysoká škola báňská - Technická univerzita. ISBN: 978-80-248-2092-7. 
[13] Mobbing: Psychický teror na pracovišti. Doktorka.cz; podle Brigitte Huberová Psychický teror na pracovišti, [online]. [vid. 6. února 2010]. Dostupné z: http://psychologie.doktorka.cz/mobbing--psychicky-teror-na-pracovisti-/

[14]NOVÁK, T. a V. CAPPONI, 1996. Sám proti agresi. 1. vydání. Praha : Grada Publishing. ISBN: 80-7169-253-0.

[15]NOVÝ, I., 1993. Podniková kultura a identita. Praha : Vysoká škola ekonomická v Praze. ISBN: 80-7079-159-4.

[16]PUTNOVÁ, A. a kol., 2000. Etika podnikání očima českých manažerů. Moderní ř́zení, 5(5), 4-6.

[17] SALÁTOVÁ, D., 2011. Mobbing: cizí slovo, které straší Čechy. IHNED.cz, [online]. [vid. 9. ledna 2010]. Dostupné z: http://vyhledavani.ihned.cz/c3-21386120-M00000_dmobbing-cizi-slovo-ktere-strasi-cechy>

[18]SVOBODOVÁ, L., 2008. Nenechte se šikanovat kolegou. 1. vydání. Praha : GradaPublishing. ISBN: 978-80-247-2474-4.

[19] SÝKOROVÁ, A., 2004. Bulletiny, č. 2, [online]. [vid. 6. února 2010]. Dostupné z: http://osz.cmkos.cz/CZ/Z_tisku/Bulletin/02_2004/mobbing.html

[20] ŠRONEK, I., 1995. Etiketa a etika v podnikání. Praha : ManagementPress. ISBN: 8085603-94-2.

[21]ŠTIKAR, J. a kol., 2000. Metody psychologie práce a organizace. 1. vydání. Praha : Nakladatelství Karolinum. ISBN: 80-246-0048-X.

[22] VALÁS̆EK, V., 1999. Hlavně to nevzdávejte. Ekonom, 43(8), 54.

[23] VALÁŠEK, V., 1998. -tes-.Problém zvaný mobbing.Moderní řizení, č. 3, s. 39-40.

[24] Volny.cz. Mobbing, [online]. [vid. 20. června 2010]. Dostupné z: http://www.volny.cz/xenobit/mobbing.html

[25]Zákon. č. 1/1993 Sb, Ústava České republiky. Portál veřejné správy. [online]. [vid. 1. května 2010]. Dostupné z:

http://portal.gov.cz/app/zakony/zakonPar.jsp?idBiblio=40450\&fulltext=\&nr=1 2F1993\& part $=\&$ name $=\& \mathrm{rpp}=15 \#$ local-content

[26]Zákon. č. 23/1991 Sb., Listina základních práv a svobod. Portál veřejné správy. [online]. [vid. 1. května 2010]. Dostupné z:

http://portal.gov.cz/app/zakony/zakon.jsp?page=0\&nr=23 2F1991\&rpp=15\#seznam

[27]Zákon. č. 40/1963 Sb., Občanský zákoník, ve znění pozdějších předpisů. Portál veřejné správy. [online]. [vid. 1. května 2010]. Dostupné z: http://portal.gov.cz/app/zakony/zakon.jsp?page=0\&nr=40 2F1964\&rpp=15\#seznam

[28]Zákon. č. 140/1961 Sb., trestní zákoník, ve znění pozdějších předpisů. [online]. [vid. 1. května 2010]. Dostupné z: http://trestnizakonik.cz/

[29]Zákon č. 262/2006 Sb., zákoník práce. Ministerstvo práce a sociálních věcí, [online]. [vid. 1. května 2010]. Dostupné z: http://www.mpsv.cz/ppropo.php?ID=z262_2006o

[30]Zákon. č. 435/2004 Sb., Zákon o zaměstnanosti, ve znění pozdějších předpisů. Ministerstvo práce a sociálních věcí, [online]. [vid. 1. května 2010]. Dostupné z: http://www.mpsv.cz/files/clanky/11911/zakon_367_2011.pdf 